Syntax Fusion: Jurnal Nasional Indonesia

e-ISSN: 2775-4440

Vol. 1, No. 10, Oktober 2021

\title{
SISTEM INFORMASI KEPEGAWAIAN PADA PT. CLOUDARON
}

\section{Fitrah Fajar Buana, Tarisno Amijoyo}

STMIK Muhammadiyah Jakarta, Indonesia.

Email: fitrafajarbuana91@gmail.com, ahbibadil@gmail.com

\begin{abstract}
Abstrak
PT Cloudaron Jaya Indonesia merupakan perusahaan yang berfokus pada Teknologi Informasi yang terus berkompetisi dalam bisnis dan untuk menjawab tantangan yang terus berkembang di industri Teknologi Informasi dalam negeri maupun tingkat global. Dalam pengelolaan SDM juga menjadi hal yang cukup penting bagi PT. Cloudaron Jaya Indonesia. yang bergerak dalam Teknologi Informasi, pengolahan pengajuan cuti, lembur, serta pengaksesan data personal para karyawannya belum dilengkapi oleh sistem komputerisasi dalam berbagai bidang. Metode yang digunakan adalah metode waterfall, yang menggambarkan metode pengembangan perangkat lunak secara sistematis dan berurutan, dimulai dari spesifikasi kebutuhan pengguna, kemudian dilanjutkan melalui tahapan perencanaan, pemodelan, pembangunan, dan penyampaian sistem kepada pelanggan atau pengguna, diakhiri perangkat lunak generasi dukungan lengkap. Hasil dari sistem berbasis web dapat mempermudah dan mempercepat akses informasi dan data yang dibutuhkan. memudahkan administrator pusat untuk memonitor sistem setiap saat karena aplikasinya sendiri berbasis web dan aman karena menggunakan jaringan lokal.
\end{abstract}

Kata Kunci: Sistem Informasi; Kepegawaian; Web

Diterima: 24-09-2021 Direvisi: 14-10-2021 Disetujui: 18-10-2021

\section{Pendahuluan}

Sistem informasi dan teknologi informasi merupakan hal dasar yang harus dimiliki untuk menjalankan kegiatan operasional organisasi atau perusahaan. Perkembangan teknologi informasi dapat memberikan kemudahan bagi masyarakat untuk melakukan berbagai aktivitas dalam organisasi dan bisnis.

PT. Cloudaron Jaya Indonesia adalah perusahaan teknologi informasi yang terus bersaing dalam bisnis dan menjawab tantangan yang berkembang dari negara dan industri teknologi informasi global. Manajemen personalia juga sangat penting bagi PT. Cloudaron Jaya Indonesia bergerak di bidang teknologi informasi, pengolahan absensi, pengajuan cuti, kerja lembur dan pengaksesan data pribadi karyawannya yang tidak lengkap melalui sistem komputerisasi di berbagai bidang. 
Dalam bukunya yang berjudul "Sistem Informasi Akuntansi", sistem adalah kumpulan atau kelompok subsistem/komponen/komponen, baik fisik maupun non fisik, yang saling berhubungan dan bekerja sama untuk mencapai tujuan tertentu (Azhar, 2013). Sementara itu, dalam bukunya "Pengenalan Sistem Teknologi Informasi", merupakan kumpulan elemen yang saling berinteraksi dalam satu kesatuan untuk melakukan proses pencapaian tujuan utama (Sutarman, n.d.).

Dapat disimpulkan bahwa sistem adalah kumpulan pengguna atau elemen yang saling berhubungan atau berinteraksi atau mempengaruhi satu sama lain ketika melakukan kegiatan bersama untuk mencapai suatu tujuan tertentu (Jogiyanto, 2009). Informasi adalah hasil pengolahan pengetahuan menjadi suatu bentuk tertentu yang lebih bermanfaat bagi penerimanya, menggambarkan kejadian yang sebenarnya dan dapat digunakan sebagai alat pengambilan keputusan (Soedaryono, 2008).

\section{Metode Penelitian}

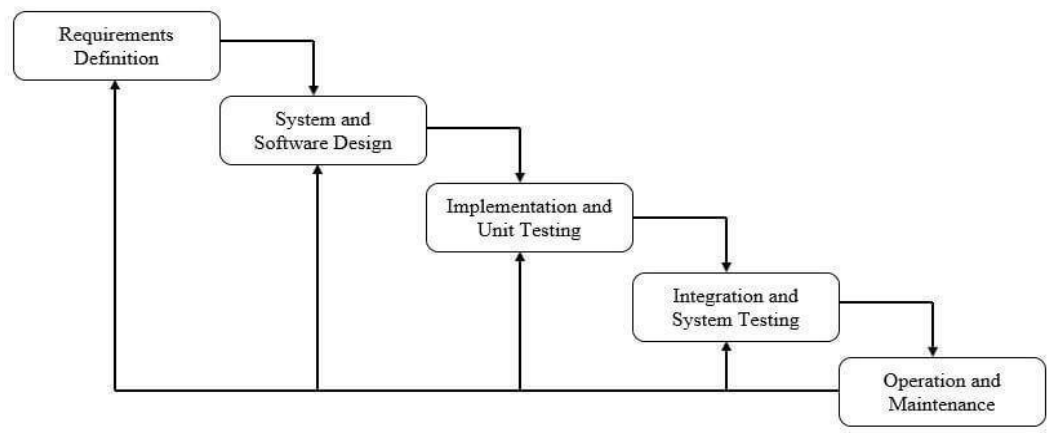

Gambar 1. Metode Waterfall

Metode waterfall atau metode air terjun adalah salah satu siklus hidup klasik dalam pengembangan perangkat lunak. Ian Sommerville menjelaskan bahwa metode waterfall memiliki lima tahapan, yaitu analisis dan definisi kebutuhan, perancangan sistem dan perangkat lunak, implementasi dan pengujian unit, integrasi dan pengujian sistem, serta operasi dan pemeliharaan (Ian Sommerville, 2011).

Metode waterfall terdiri dari 5 tahapan yaitu:

\section{Requirement Definition}

Sebelum mengembangkan perangkat lunak, pengembang harus mengetahui dan memahami bagaimana pengguna membutuhkan informasi tentang perangkat lunak.

2. System and Software Design

Kemudian pada tahap ini, informasi tentang spesifikasi kebutuhan dari tahap analisis kebutuhan dianalisis, kemudian diimplementasikan dalam pengembangan dan perancangan. Tujuan dari perancangan adalah untuk membantu memberikan gambaran yang lengkap tentang pekerjaan yang harus dilakukan. 


\section{Implementation And Unit Testing}

Tahap implementasi dan pengujian unit adalah tahap pemrograman. Pengembangan perangkat lunak dibagi menjadi modul-modul kecil, yang akan digabungkan pada tahap berikutnya.

4. Integration and System Testing

Semua unit atau modul yang telah dikembangkan dan diuji pada tahap implementasi kemudian diintegrasikan ke dalam sistem secara keseluruhan.

5. Operation dan Maintenance

Pada tahap akhir dari metode waterfall, perangkat lunak yang telah selesai dioperasikan dan dipelihara oleh pengguna.

\section{Hasil dan Pembahasan}

1. Analisa kebutuhan perangkat keras

Persyaratan minimum dan direkomendasikan untuk menggunakan aplikasi sistem informasi kepegawaian ini adalah sebagai berikut::

Tabel 1. Kebutuhan perangkat keras (Hardware)

\begin{tabular}{cl}
\hline No & \multicolumn{1}{c}{ Hardware } \\
\hline 1 & Intel Core i3-3320 \\
\hline 2 & Memori RAM 4GB \\
\hline 3 & Harddisk 1 GB \\
\hline
\end{tabular}

2. Analisa kebutuhan perangkat lunak

Adapun perangkat lunak untuk membangun program ini adalah sebagai berikut:

Tabel 2. Kebutuhan perangkat lunak (Software)

\begin{tabular}{cl}
\hline No & \multicolumn{1}{c}{ Software } \\
\hline 1 & Sistem Operasi Microsoft \\
& Windows 10 \\
\hline 2 & Google Chrome \\
\hline 3 & Sublime Text 3 \\
\hline 4 & XAMPP \\
\hline
\end{tabular}

3. Analisa Sistem Yang Berjalan

Sistem pengolahan data yang saat ini digunakan di PT. Cloudaron masih secara manual menemui banyak kendala seperti keterlambatan pengumpulan data, penumpukan penyimpanan data, dan kehilangan sebagian data. 


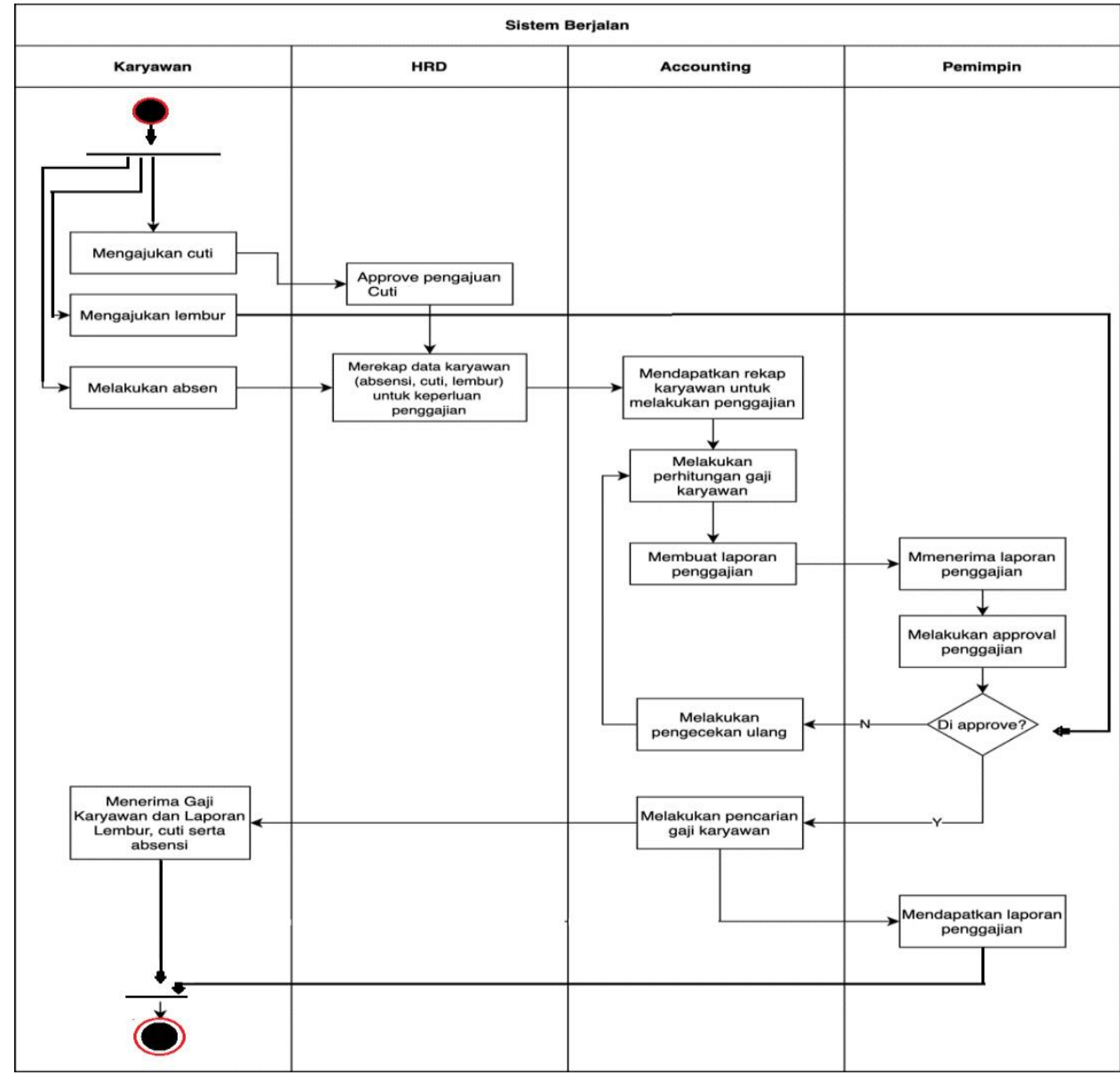

Gambar 2. Sistem Kepegawaian Yang Sedang Berjalan

4. Sistem Yang Diusulkan

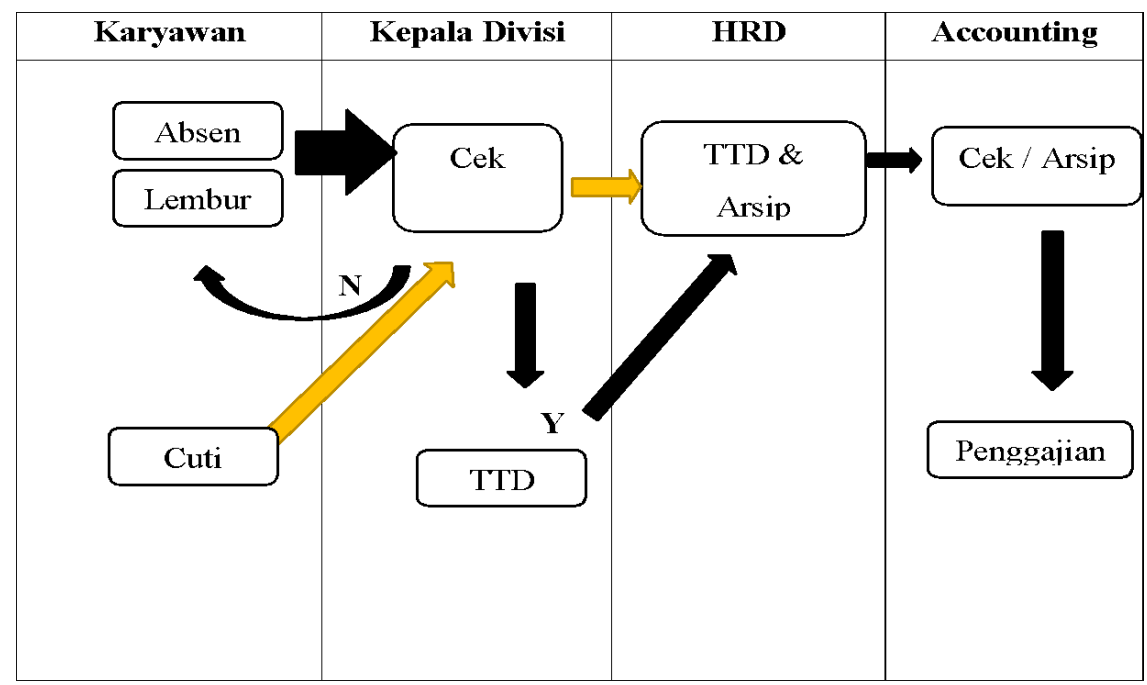

Gambar 3. Sistem yang diusulkan 
Dalam analisis yang diusulkan, ada empat peserta, yaitu: HRD, akuntansi, kepala departemen, dan karyawan. Karyawan dapat tidak masuk kerja, meminta cuti dan bekerja lembur Kepala departemen melakukan persetujuan dan inspeksi, supervisi dan persetujuan pengembangan sumber daya manusia, detail inspeksi akuntansi dan penggajian.

\section{Implementasi}

a. Tampilan Halaman Login

Halaman Login pada sistem kepegawaian berbasis web pada PT. Cloudaron, saat membuka web home awal seperti di gambar ini.

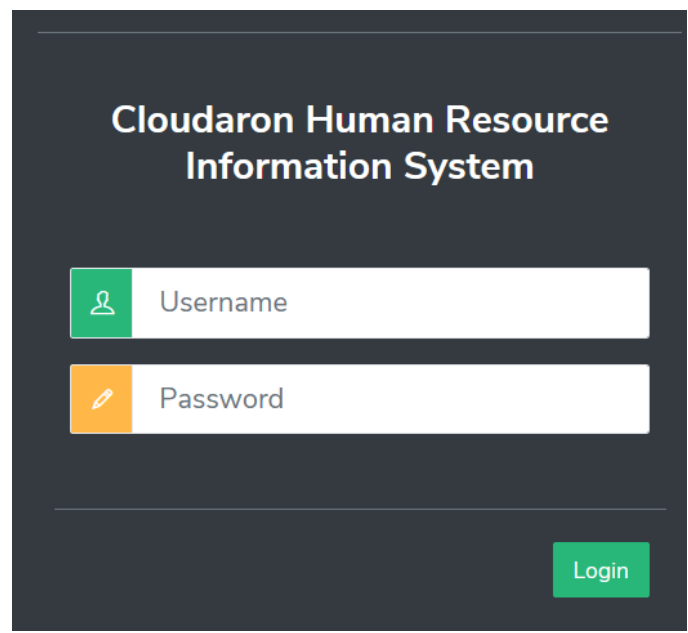

Gambar 4. Tampilan Login

b. Tampilan Informasi Kesalahan Pengisian Data Login

Apabila data yang diinputkan tidak benar, maka sistem memberikan informasi kesalahan seperti gambar.

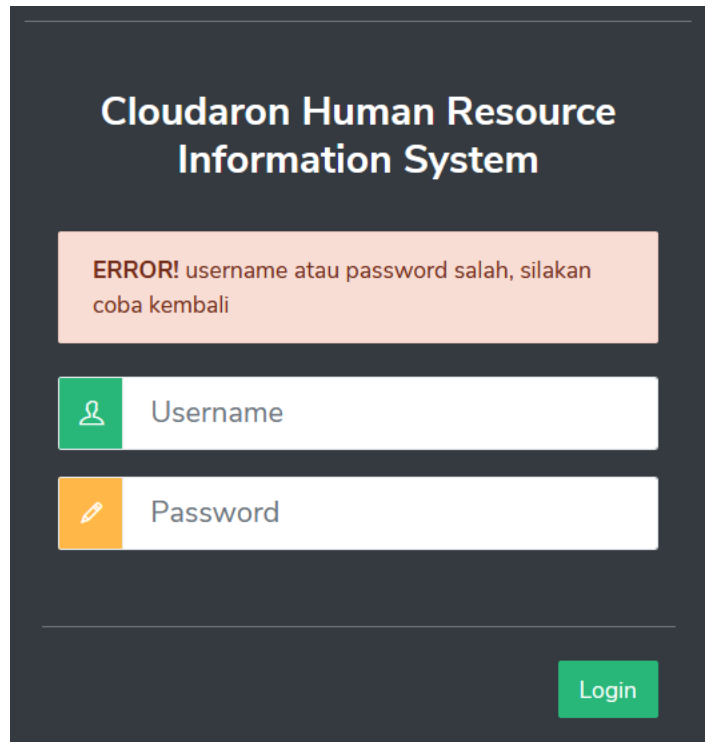

Gambar 5. Halaman Kesalahan Login 


\section{c. Halaman HRD}

HRD bisa melakukan penambahan data karyawan, data user, data divisi dan approval serta pengecekan rinci cuti karyawan, berikut hasil implementasi halaman HRD.

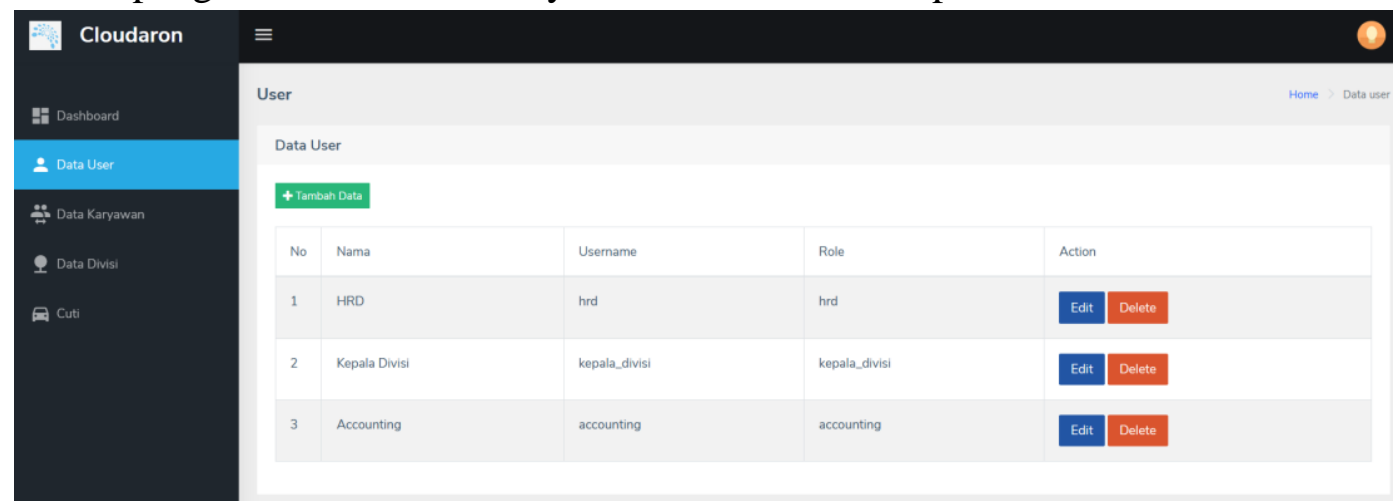

\section{Gambar 6. Halaman HRD}

d. Halaman Accounting

Accounting bisa tambah pendataan gaji pokok karyawan, cek detail absensi, cek detail lembur, cek detail cuti dan penggajian. Berikut hasil implementasi halaman Accounting.

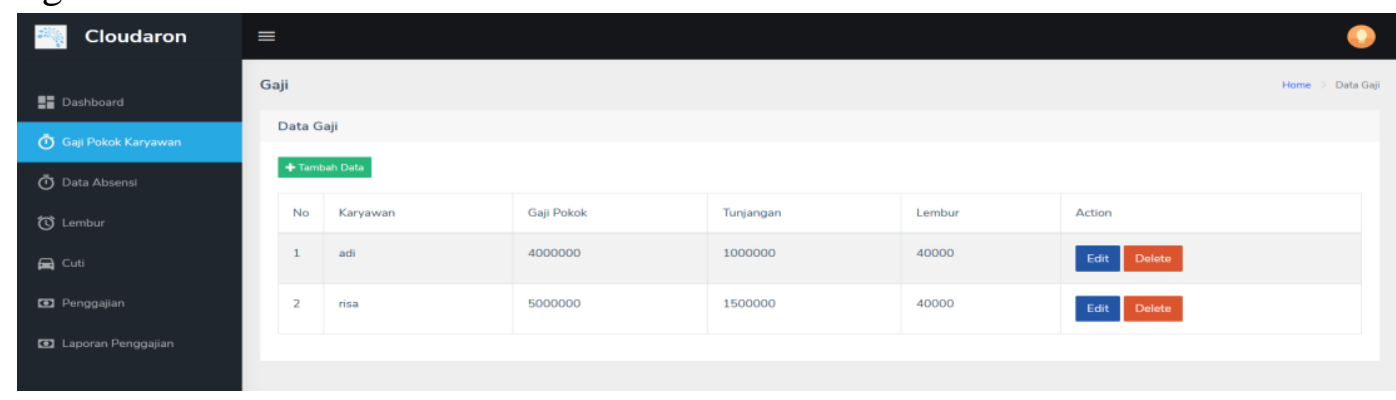

\section{Gambar 7. Halaman Accounting}

e. Tampilan Halaman Karyawan

Karyawan bisa melakukan absensi, pengecekan slip gaji, pengajuan lembur, cuti dan edit profile pribadi karyawan, berikut hasil implementasi halaman Karyawan.

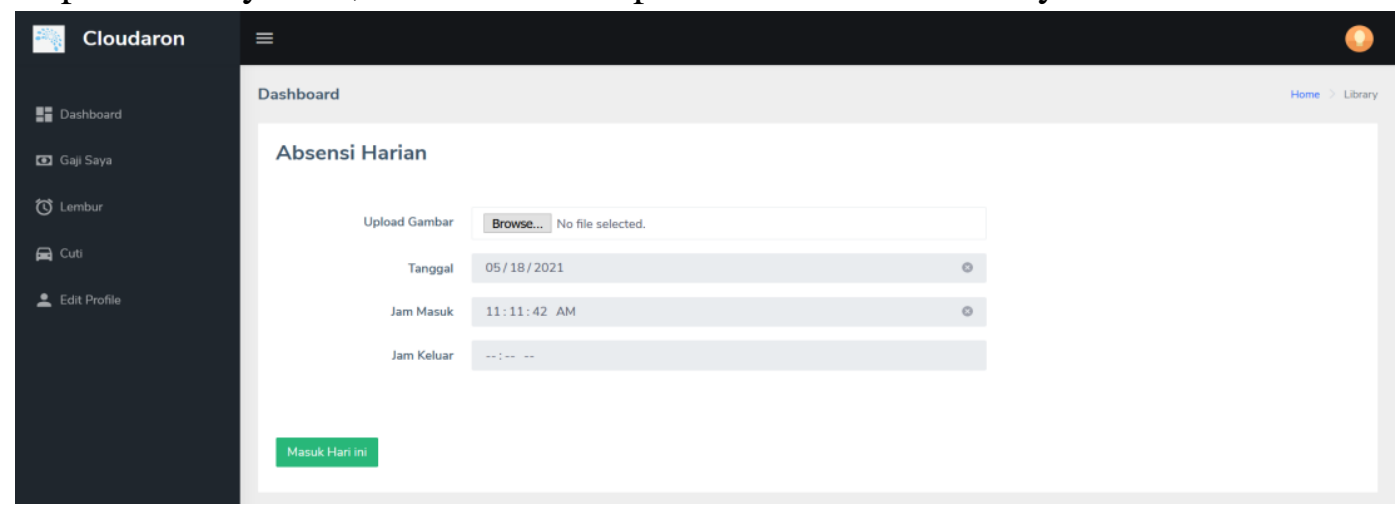

Gambar 8. Tampilan Halaman Karyawan 
Fitrah Fajar Buana, Tarisno Amijoyo

f. Tampilan Halaman Kepala Divisi

Kepala divisi bisa melakukan approve lembur, pengecekan cuti dan pengecekan serta approve penggajian karyawan.

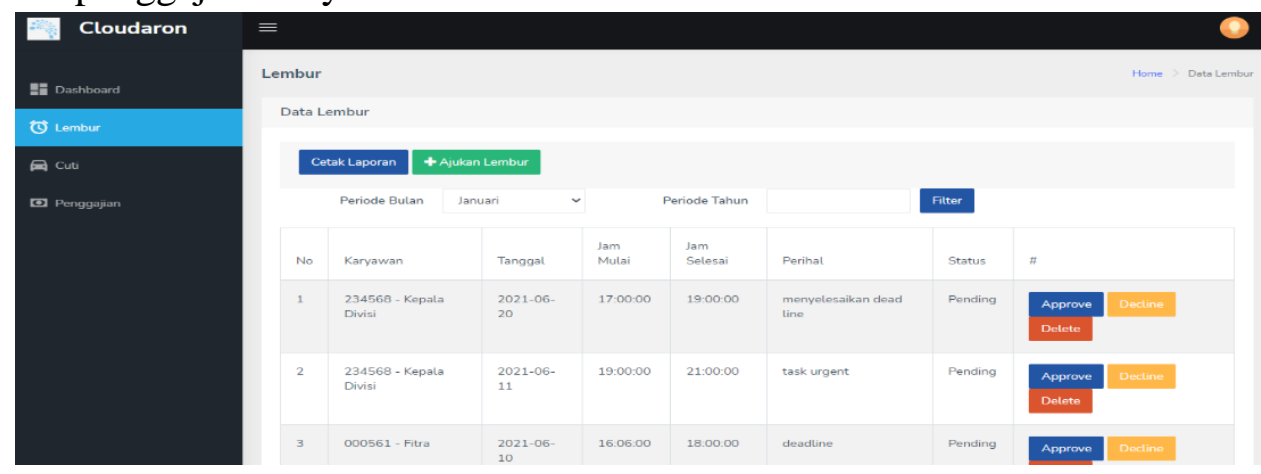

Gambar 9. Tampilan Halaman Kepala Divisi

6. Pengujian

Pengujian dilakukan untuk mengetahui apakah fungsi yang telah dibuat berjalan sesuai dengan yang diinginkan.

a. Rencana pengujian

Tabel 3. Rencana Pengujian

\begin{tabular}{cll}
\hline No. & \multicolumn{1}{c}{ Item Yang Diuji } & \multicolumn{1}{c}{ Jenis Pengujian } \\
\hline 1 & Halaman & Black Box \\
\hline 2 & Pengolahan Data Karyawan & Black Box \\
\hline 3 & Pengolahan Data Divisi & Black Box \\
\hline 4 & Pengolahan Data Absensi & Black Box \\
\hline 5 & Pengolahan Data Cuti & Black Box \\
\hline 6 & Pengolahan Data Lembur & Black Box \\
\hline 7 & Pengolahan Data Gaji & Black Box \\
\hline 8 & Pengolahan Data Profile & Black Box \\
\hline
\end{tabular}


b. Hasil Uji

Tabel 4. Hasil Uji Coba Karyawan

\begin{tabular}{|c|c|c|c|}
\hline No & Halaman Uji & Cara Pengujian & Hasil \\
\hline 1. & Login Karyawan & $\begin{array}{l}\text { 1. Pengguna membuka } \\
\text { halaman sistem } \\
\text { 2. mengisi username dan } \\
\text { password. } \\
\text { 3. Tekan tombol "Login" } \\
\text { 4. Sistem melakukan validasi } \\
\text { Login. }\end{array}$ & Berhasil \\
\hline 2. & Data Gaji & 1. Buka Menu Gaji Saya & Berhasil \\
\hline 3. & Data Lembur & 1. Buka Menu Lembur & Berhasil \\
\hline 4. & Data Cuti & 1. Buka Menu Cuti & Berhasil \\
\hline 5. & Edit Profil & $\begin{array}{l}\text { 1. Buka Menu Edit Profile } \\
\text { 2. Ubah data profil } \\
\text { 3. Tekan tombol "Update" }\end{array}$ & Berhasil \\
\hline
\end{tabular}

Tabel 5. Hasil Uji Coba Accounting

\begin{tabular}{|c|c|c|c|}
\hline No & Halaman Uji & Cara Pengujian & Hasil \\
\hline 1. & Login Accounting & $\begin{array}{l}\text { 1. Pengguna membuka } \\
\text { halaman sistem } \\
\text { 2. mengisi username dan } \\
\text { password. } \\
\text { 3. Tekan tombol "Login" } \\
\text { 4. Sistem melakukan validasi } \\
\text { Login. }\end{array}$ & Berhasil \\
\hline 2. & Kelola Data Gaji & $\begin{array}{l}\text { 1. Buka Menu Gaji Pokok } \\
\text { Karyawan } \\
\text { 2. Tekan tombol tambah untuk } \\
\text { Melakukan penambahan data } \\
\text { gaji. } \\
\text { 3. Tekan tombol "lihat/edit" } \\
\text { untuk merubah data gaji yang } \\
\text { sudah ada. }\end{array}$ & Berhasil \\
\hline
\end{tabular}




\begin{tabular}{lclll}
\hline & & 4. & $\begin{array}{l}\text { Tekan tombol "hapus" untuk } \\
\text { menghapus data gaji yang } \\
\text { sudah ada. }\end{array}$ & \\
\hline 3. & Data Absensi & 1. & Buka Menu Data Absensi & Berhasil \\
\hline 4. & Data Lembur & 2. & Buka Menu lembur & Berhasil \\
\hline 5. & Data Cuti & 2. & Buka Menu Cuti & Berhasil \\
\hline 6. & Data Penggajian & 1. & Buka Menu Penggajian & Berhasil \\
\hline 7. & Laporan Penggajian & 1. & $\begin{array}{l}\text { Buka menu Laporan } \\
\text { Penggajian }\end{array}$ & Berhasil \\
\hline
\end{tabular}

Tabel 6. Hasil Uji Coba HRD

\begin{tabular}{|c|c|c|c|}
\hline No & Halaman Uji & Cara Pengujian & Hasil \\
\hline 1. & Login HRD & $\begin{array}{l}\text { 1. Pengguna membuka } \\
\text { halaman sistem } \\
\text { 2. mengisi username dan } \\
\text { password. } \\
\text { 3. Tekan tombol "Login" } \\
\text { 4. Sistem melakukan validasi } \\
\text { Login. }\end{array}$ & Berhasil \\
\hline 2. & Kelola Data User & $\begin{array}{l}\text { 1. Buka Menu Data User } \\
\text { 2. Tekan tombol tambah untuk } \\
\text { Melakukan penambahan data } \\
\text { user. } \\
\text { 3. Tekan tombol "lihat/edit" } \\
\text { untuk merubah data user } \\
\text { yang sudah ada. } \\
\text { 4. Tekan tombol "hapus" untuk } \\
\text { menghapus data user yang } \\
\text { sudah ada. }\end{array}$ & Berhasil \\
\hline 3. & Kelola Data Karyawan & $\begin{array}{l}\text { 1. Buka Menu Data Karyawan } \\
\text { 2. Tekan tombol tambah untuk } \\
\text { Melakukan penambahan data } \\
\text { karyawan. } \\
\text { 3. Tekan tombol "lihat/edit" } \\
\text { untuk merubah data } \\
\text { karyawan yang sudah ada. } \\
\text { 4. Tekan tombol "hapus" untuk } \\
\text { menghapus data karyawan } \\
\text { yang sudah ada. }\end{array}$ & Berhasil \\
\hline 4. & Kelola Data Absensi & 1. Buka menu Data Absensi & Berhasil \\
\hline
\end{tabular}




\begin{tabular}{|c|c|c|c|}
\hline 5. & Kelola Data Divisi & $\begin{array}{l}\text { 1. Buka Menu divisi } \\
\text { 2. Tekan tombol tambah untuk } \\
\text { Melakukan penambahan data } \\
\text { divisi. } \\
\text { 3. Tekan tombol "lihat/edit" } \\
\text { untuk merubah data divisi } \\
\text { yang sudah ada. } \\
\text { 4. Tekan tombol "hapus" untuk } \\
\text { menghapus data divisi yang } \\
\text { sudah ada. }\end{array}$ & Berhasil \\
\hline 6. & Data Cuti & 2. Buka menu Cuti & Berhasil \\
\hline 7. & Kelola Data Lembur & 1. Buka menu Lembur & Berhasil \\
\hline
\end{tabular}

Tabel 7. Hasil Uji Coba HRD

\begin{tabular}{|c|c|c|c|}
\hline No & Halaman Uji & Cara Pengujian & Hasil \\
\hline 1. & Login Kepala Divisi & $\begin{array}{l}\text { 1. Pengguna membuka } \\
\text { halaman sistem } \\
\text { 2. mengisi username dan } \\
\text { password. } \\
\text { 3. Tekan tombol "Login" } \\
\text { 4. Sistem melakukan validasi } \\
\text { Login. }\end{array}$ & Berhasil \\
\hline 2. & Data Lembur & $\begin{array}{l}\text { 1. Buka menu lembur } \\
\text { 2. Approve/reject data lembur }\end{array}$ & Berhasil \\
\hline 3. & Data Cuti & $\begin{array}{l}\text { 1. Buka menu Cuti } \\
\text { 2. Tekan tombol "Cetak } \\
\text { Laporan" untuk print out } \\
\text { data }\end{array}$ & Berhasil \\
\hline
\end{tabular}

\section{Kesimpulan}

Berdasarkan hasil analisa, implementasi serta pengujian pada sistem pemesanan catering berbasis web pada PT Catering Service Utama disimpulkan dengan adanya sistem pemesanan catering ini untuk mempermudah dalam hal pemesanan. Dengan adanya sistem pemesanan catering ini dapat membantu penjualan dan pemesanan pada PT Catering Service Utama lebih efisien. 
Fitrah Fajar Buana, Tarisno Amijoyo

\section{BIBLIOGRAFI}

Azhar, Susanto. (2013). Sistem Informasi Akuntansi. Bandung: Lingga Jaya, 5(1). Google Scholar.

Hamidini, M. D. (2017). Analisis dan Perancangan Sistem Informasi Pembahasan Secara Praktis dengan Contoh Kasus. Deepublish. Google Scholar.

Ian Sommerville (2011), Socio-technical systems: From design methods to systems engineering. Jurnal Intracting With Computer. Google Scholar.

Jogiyanto, 2009. Sistem Informasi Manajemen. Yogyakarta: Penerbit Andi. Hal 34 Google Scholar.

Purnawan, Nunu Nugraha, Rian Piarna, and Rani Merlinda. 2020. "Rancang Bangun Human Resource Information System Modul Time Management." Jurnal Ilmiah Ilmu Dan Teknologi Rekayasa 2 (2): 67-75. https://doi.org/10.31962/jiitr.v2i2.2. Google Scholar.

Soedaryono, Tata Laksana Kantor edisi 6 (Jakarta: Bumi Aksa,2008), halaman 6 Google Scholar.

Sutarman, M. (n.d.). Kom. 2009.“pengantar teknologi informasi”, Edisi pertama. Bumi Aksara. Jakarta. Google Scholar 